\title{
Framing Improvement of Emergency Services RSKJ Soeprapto Hospital with Lean and WAM Modification
}

\author{
Erlina Puspitaloka Mahadewi ${ }^{1 *}$, Ade Heryana ${ }^{2}$, Fori Yumita ${ }^{3}$, \\ Mulyo Wiharto ${ }^{4}$, Lia Amalia ${ }^{5}$ \\ ${ }^{1,2,4}$ Faculty of Health Sciences, Esa Unggul University Jakarta Indonesia 11510 \\ ${ }^{3}$ RSKJ Soeprapto Hospital Jalan Bhakti Husada, Lingkar Barat, \\ Bengkulu Province Indonesia 38255 \\ ${ }^{5}$ Faculty of Economic and Business, Esa Unggul University Jakarta Indonesia \\ ${ }^{*}$ Corresponding author: \\ Email: erlina.puspitaloka@esaunggul.ac.id
}

\begin{abstract}
.
The present study reports the first comprehensive research on covid19 emergency services model. Healthcare services inside hospitals during pandemic can apply the Lean Hospital and Waste Assessment Model (WAM) modification, which is a new method that can be used to identify waste in the hospital service process flow and operational of emergency service. The purpose of this study is to provide recommendations for improving emergency services in the covid19 era. The method used in this research is a descriptive qualitative analysis carried out through observing the service flow of patients who will be hospitalized from the emergency, confirming the service flow by in-depth interviews and looking at secondary data and giving a questionnaire on a modification of eight waste relationship at 15 persons expert who understands the emergency service process. The results showed that the critical waste of emergency services at RSKJ Soeprapto hospital is a waste of human skills of $17.5 \%$. The reasons for the emergence above are because the covid19 team has not yet been formed, the absence of special officers to conduct primary triage before the patient enters the emergency unit, and many officers who do not understand the flow of emergency services in the covid19 pandemic era. In order to improve hospital services in the future, it is necessary to form a covid19 team, to develop a standard emergency service guide, to conduct continuous socialization to all the hospital staff through education and training programs, which are recommendations for improving emergency services at RSKJ Soeprapto Hospital Bengkulu in the pandemic era and new normal preparation.
\end{abstract}

Keywords: Covid19, emergency unit, hospital services, lean hospital, waste assessment model

\section{INTRODUCTION}

In accordance with directives and standards the World Health Organization WHO) during the covid19 pandemic standard for the emergency unit and emergency room (ER) inside hospital is required to be more selective in accepting patients[1]. Screening of patients must be rapid but also very carefull also selective. The emergency room should be able to separate ARI (Acute Respiratory Infection) and non-ARI patients before entering the hospital area which is called the primary triage area. If http://ijstm.inarah.co.id 
after the patient screening in the primary triage, the patient is proven to have ARI[2]. Then the patient must be screened for covid19 in the secondary triage according to existing guidelines, such as laboratory examinations, chest X-rays, and rapid tests, even thorax CT scan or PCR swab for hospitals that are available. After it is proven that it is not covid19, the new patient can be transferred to a non-ISPA emergency room, but otherwise the patient must be immediately put in an isolation room or sent home to carry out independent isolation and be monitored by the local health office [3][4].

Based on these provisions, the covid19 era requires hospitals and all other health services to make policy changes to the service process flow, including for special psychiatric hospitals such as RSKJ Soeprapto Bengkulu. Since the pandemic and covid19 in March 2020, all emergency room (ER) patients with good hospitalization plans are required to screen for covid19 with anamnesis, physical examination, and laboratory examinations of complete blood, according to covid19 screening, namely complete blood. In contrast to the standard stipulated that patient screening is carried out in the primary triage area which is carried out before the patient enters the ER, at RSKJ Soeprapto Bengkulu, screening is carried out in the ER by the ER team, which causes patient care in the emergency to be longer and ultimately causes a buildup of patients in the ER. Even though in the era of covid19, every service unit must not experience a congestion of patients to prevent and minimize the transmission of the spread of covid19 infection[5].

The absence of special officers to carry out screening, and the absence of policies that comply with standards and the absence of a covid19 team are the main causes of this happening[6]. Lean Hospital is a system of operational management that useful for the health service to improve the flow of hospital services, to eliminate waste. In the lean hospital management concept, waste can be defined as all work activities that do not provide added value in the process of transforming input into output in each process flow so that all types of waste that exist along the process flow that transform input into output must be eliminated in order to increase the value of the product (goods or services) and further increase customer value. So based on the background of the description above, this research was carried out aimed at improving emergency services in the era of covid19 by identifying waste so that they can find recommendations for improvements to be applied in RSKJ Soeprapto Hospital in Bengkulu Province[7].

\section{METHODS}

The research is a type of case and field study with a qualitative descriptive analytic research design. The research data was taken through participatory observation to the flow of inpatients from the ER. After making observations, researchers confirmed through in-depth interviews, and gave questionnaires to 15 (fifteen) expert respondents who understood emergency services. Researchers also obtained secondary 
data by looking at the patient's medical records, and several policies, that had existed at the research location. The location of the study was the emergency unit (ER) of RSKJ Soeprapto Hospital Bengkulu and several related units related to the ER such as laboratories, EDP (Entering Patient Data), medical records, inpatient administration and finence staff like cashiers. The study was conducted from June to December 2020 in emergency room patients who were advised to be hospitalized until the patient moved to the inpatient room on morning, afternoon, and night shifts.

Data analysis was carried out by identifying critical waste with the Waste Assessment Model (WAM) modification from Lean Management Hospital. The Critical Waste which was found to be analyzed the cause of the problem with a Fishbone Diagram and then determined recommendations based on the results of indepth interviews. Data collection (primary data) is done by: 1. observation of the flow of inpatient services from the emergency unit and emergency rooms, 2. in-depth interview, and with 3. the questionnaires. Analytical techniques selected to conduct this investigation in field and in-depth interview are based on the suitability for the problems[8]. Therefore, the instrument and parameters must meet with standards regarding questionnaires and WAM modification.

\section{RESULT AND DISCUSSION}

The hospital emergency unit, which is the first common area that patients go to, is the main focus in controlling this safety. The royal college of emergecy medicine recommends emergency service standards with 5 (five) main bases with namely[9]:

1. Emergency Unit (UGD) must be a sterile place from nosocomial infections so as to protect patients;

2. The Emergency Unit (UGD) should not experience a congestion of patients or their families;

3. The entire hospital area should not be too crowded;

4. The emergency room must be designed according to standards to maintain patient safety;

5. The Emergency Unit (UGD) must also be a safe place for both medical and non-medical workers.

The above strategy was refined by WHO (World Health Organization) by issuing a strategy to prevent and limit the risk of transmission of covid19 infection on May 2020, consisting of Standard emergency services during the pandemic covid19 [10]:

1. Take standard precautions for all patients. Standard precautions in this regard are always washing hands, doing and teaching patients how to cough and or sneeze, use Personal Protective Equipment (PPE) according to the risk of contact and droplet transmission, practice safe injections, management of sharp objects and prevention of wounds. safe, carry out handling, cleaning and 
disinfection of patient care equipment safely, cleaning the environment, handling and washing used linen safely, and properly managing waste.

2. Conducting triage, knowing early on the possibility of covid19 and isolating covid 19 patients. Use of clinical triage in health care facilities for the purpose of early identification of patients with acute respiratory infections (ARI) to prevent the transmission of pathogens to health professionals and other patients.

3. Perform administrative control

a. This activity is the first priority and the PPI strategy includes the provision of infrastructure policies and procedures to prevent, detect and control infections during health care. Activities will be effective if carried out starting from anticipating the flow of the patient from the first time he arrives to leaving the health service facility. Important steps in administrative control include early identification of the patient, implementing prompt and precise preventive measures, and controlling the source of infection.

b. Carry out environmental and engineering controls. These activities are carried out including in the infrastructure of basic health care facilities and in households that treat patients with mild symptoms and do not require hospital treatment. This activity needed for aimed at ensuring that adequate environmental ventilation in all areas within health care facilities as well as in households, as well as adequate environmental hygiene. Must maintain a minimum distance of 1 (one) meter between each patient and other patient, including health workers (if not wearing PPE).

4. Perform additional empirical precautions (droplet, contact, airbone recautions)

a. Contact prevention measures: providing patient care with a single room principle so that the patient stays in the room, performs hand hygiene with 5 (five) moments, uses appropriate PPE (robes, masks, and gloves), performs equipment cleaning (decontamination), and perform environmental cleaning.

b. Splash prevention measures (droplet): perform hand hygiene for 5 (five) moments, provide single room service for patients or separate patients from other patients at least 1 meter away, health workers use appropriate PPE (surgical mask, eye / face mask), and the patient must remain in the room (limited movement);

c. Measures for prevention of air transmission (in the context of COVID19): all steps taken to prevent contact and droplets. It's just that, the mask used is the N95 mask.

Elimination of waste in Emergency Unit (ER) services in the era of the covid19 pandemic can prevent the accumulation of patients so as to prevent the transmission of covid19 infection transmission, both to patients and or workers in 
hospitals[11]. The purpose of this is to provide recommendations for improving emergency services in the covid19 era, so that the hospital can maintain the quality of service by preventing the accumulation of patients and implementing PPI standards[12]. The application of Lean principles according in the third edition of the Lean Hospital, consists of two parts, namely:

1. Total Elimination of Waste.

All waste must be eliminated or minimized in order to reduce hospital costs, increase patient satisfaction and improve patient and employee safety[13]. Waste of waste is any activity that does not help the patient's healing process[14]. Examples of waste activity that often occurs in hospitals are as follows:

a. Waiting time for the patient to be examined by the doctor

b. Waiting time for the patient for the next stage of services

c. There is an error that endangers the patient

d. Unnecessary movements, for example, where hospital staff such as pharmacies and cashiers are far away from the service area.

\begin{tabular}{|l|l|}
\hline $\begin{array}{l}\text { Waste } \\
\text { of } \\
\text { Defect }\end{array}$ & $\begin{array}{l}\text { Providing inappropriate healthcare, the first time it takes time and } \\
\text { materials to fix it. Serious mistakes in the hospital can cause disability } \\
\text { and even death of the patient. This improper service can be caused by } \\
\text { wrong processing, misinformation and errors that involve many } \\
\text { people, such as errors when taking the patient's blood, or the nurse not } \\
\text { checking the dose of the drug given to the patient. }\end{array}$ \\
\hline $\begin{array}{l}\text { Waste of } \\
\text { Over } \\
\text { Production }\end{array}$ & $\begin{array}{l}\text { Production or supply of products that do not match patient demands, } \\
\text { for example returning drugs to pharmacies. }\end{array}$ \\
\hline $\begin{array}{l}\text { Waste of } \\
\text { Transportati } \\
\text { on }\end{array}$ & $\begin{array}{l}\text { Unneeded transfers of patients and products in the system, for } \\
\text { example registration counters and services are located not side by } \\
\text { side, so patients need a long time. }\end{array}$ \\
\hline $\begin{array}{l}\text { Waste of } \\
\text { Waiting }\end{array}$ & $\begin{array}{l}\text { The period of time that causes patients or products or employees to be } \\
\text { unable to carry out activities in the next steps. }\end{array}$ \\
\hline $\begin{array}{l}\text { Waste of } \\
\text { Inventory }\end{array}$ & $\begin{array}{l}\text { Related to tools, equipment, and materials that are available in } \\
\text { excessive quantities }\end{array}$ \\
\hline $\begin{array}{l}\text { Waste of } \\
\text { Motion }\end{array}$ & $\begin{array}{l}\text { Movement of employees who are not required to perform work, such } \\
\text { as medical staff or nurses, have to walk long distances to carry out } \\
\text { examinations on patients. }\end{array}$ \\
\hline $\begin{array}{l}\text { Waste of } \\
\text { Over } \\
\text { Processing }\end{array}$ & $\begin{array}{l}\text { Perform activities that are more than the patient's needs, such as } \\
\text { taking large blood specimens for centrifugation. }\end{array}$ \\
\hline $\begin{array}{l}\text { Waste of } \\
\text { Human Skill }\end{array}$ & $\begin{array}{l}\text { In connection with the motivation and psychological conditions of } \\
\text { employees in carrying out work, for example hospital employees who } \\
\text { do work forcibly or in a bad mood will not give optimal results. }\end{array}$ \\
\hline
\end{tabular}

Fig. 1. Types of Waste Lean Hospital 


\section{Employee Respects}

The respect referred to in lean is to motivate hospital employees or staff to do their job better and more constructively. Respect of people also has a broad meaning, how leaders are committed and trust their employees to participate in helping solve problems, reduce waste, motivate employees to care more about patients and the hospital environment without them feeling bored and forced, building cooperation between executive and management employees, so that there is no assumption that management regulates the system, solves problems, makes decisions, while implementing employees only carry out instructions[15].

Waste Assessment Model (WAM) which consists of Waste Relationship Matrix (WRM) and Waste Matrix Value (WMV). This model has the advantage of a simple matrix and a questionnaire that covers many things and is able to contribute to achieving accurate results in identifying the relationship between existing waste and also the causes of waste. The principle of using the Waste Assessment Model is the waste relationship in Lean which focuses on Sevent Waste Relationship. All wastes depend on each other, influence and are influenced by each other. The relationship between wastes is indeed very complex because it is caused by the influence of each waste that can appear directly or indirectly. The relationship between one waste and another can be symbolized by using the first letter in each waste. $O$ for Overproduction, I for Inventory, D for Defect, $\mathrm{M}$ for Motion, $\mathrm{P}$ for Process, $\mathrm{T}$ for Transportation and $\mathrm{W}$ for Waiting. The following is the relationship between waste that has been described on the hospital Lean Management[7].

In Figure1 and Figure2, all of these influencing relationships amount to 31 relationships between types of waste $i$ and affecting types of waste $j\left(i \_j\right)$. Then asked six questions with a scoring guide with each answer having a weight range of $0-4$, where the relationship between waste is symbolized using the first letter in each waste. The six questions above will be asked for each relationship or waste so that there are total of 186 (31 relationships x 6 questions).

The scores obtained from the six questions for each relationship between the wastes are then totaled to obtain the total value for each relationship. The total value is then converted to a symbol of the strength of the relationship (A, I, U, E, O, and X) following the conversion rules shown separately. The results of the conversion are then used again to calculate the level of influence of each type of waste to other types of waste with values $\mathrm{A}=10, \mathrm{E}=8, \mathrm{I}=6, \mathrm{O}=4, \mathrm{U}=2$, and $\mathrm{X}=0$. will be added and the value of the level of influence is known which is written in units (\%) or known as the waste matrix value. After the results in (\%) appear, the largest waste is chosen to be used as critical waste to find the root of the problem. 


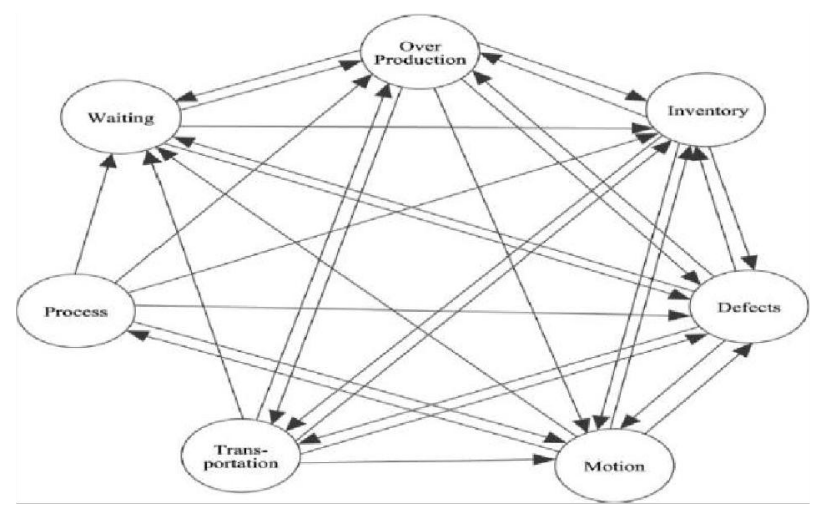

Fig. 2. Seven Waste Relationship on Lean Management

Fishbone diagram or also known as cause or effect diagram is a 5 (five) structured approach in hospital or health industry management that is possible to carry out a more detailed analysis in finding the causes of a problem, mismatches, and gaps that occur to the functions of the fishbone diagram are: summarize the causes for variations in the process, identify the categories and sub-categories of causes that affect a certain quality characteristic, provide instructions regarding the types of data that need to be collected. The fishbone structure diagram consists of a head and bones. The head represents the problem to be solved and the bones contain the causes of the problem which are grouped into six parts, namely man, measurement, method, material, machine, and environment.

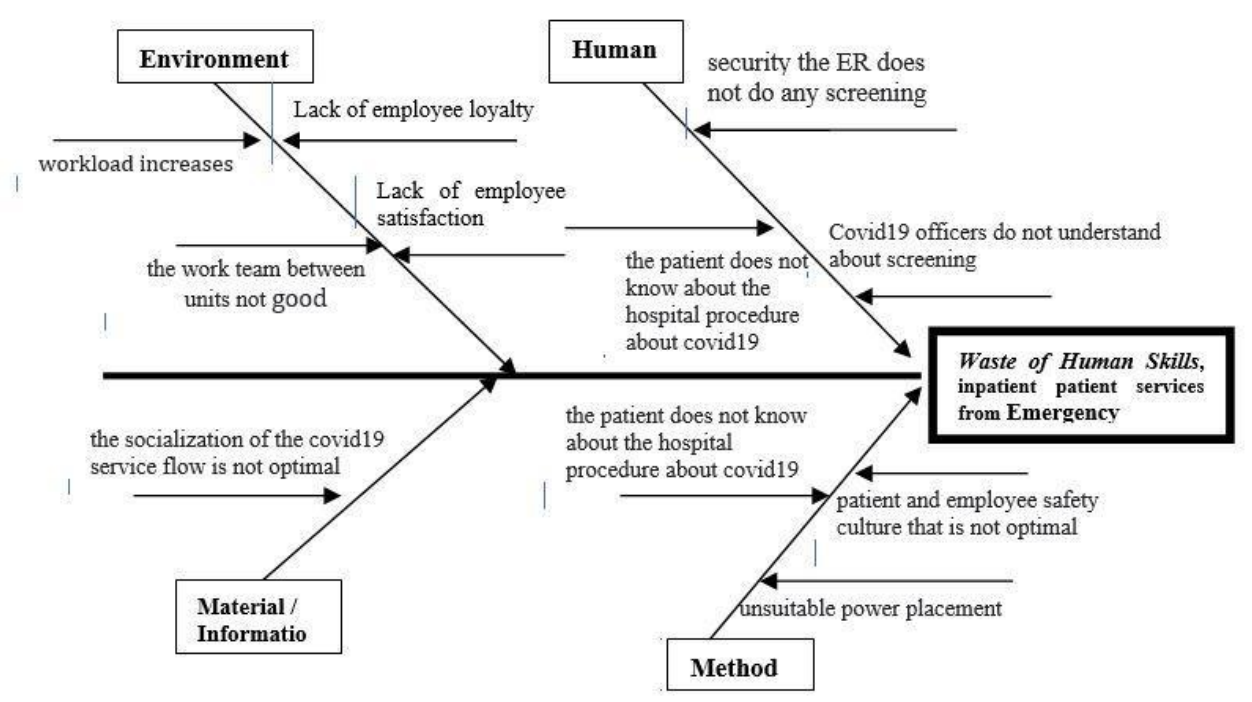

Fig. 3. Analysis the cause of Critical Waste of Human Skill at Fishbone Diagram 
Since RSKJ Soeprapto Bengkulu was designated as the National Referral Hospital, the number of emergency room visits has increased, especially during the covid 19 pandemic. From 2018 to May 2020 the number of patient visits increased every year. Based on 2020 monthly data from January to June, it can be concluded that after the pandemic that entered Indonesia in March 2020, the number of patient visits has decreased significantly[16]. However, if you look at the distribution based on specialization, from the total number of patient visits that have decreased, the number of psychiatric referral patients who visited the RSKJ Soeprapto Bengkulu emergency room and were hospitalized was still the highest number compared to other specialities. This is evidenced by the distribution report of inpatients from the emergency unit in 2020 from January to July. Emergency Unit (ER) of RSKJ Soeprapto Hospital Bengkulu not only serves true emergency patients but also serves other false emergency patients such as general patients specifically for employees and general mental health polyclinic which takes place on weekdays. The main cause of the congestion at this time is the mixing of true emergency and false emergency patients. In Figure 3 above, the mixing of false emergency and true emergency patients is basically not in accordance with the ecision of the minister of health in the emergency services guidelines which state that false emergency patients should enter the 24-hour polyclinic area[2]. The accumulation of patients due to a mixture of true emergency and false emergency patients is also not in accordance with the flow of handling covid19 which recommends that the emergency room during the covid19 era should prevent the accumulation of patients and their families[17].

At the world level, the WHO (World Health Organization) issued a standard to prevent and limit the risk of transmission of covid19 infection which consists of conducting primary triage of patients to separate infectious and non-infectious patients, then for infectious patients, isolation must be carried out immediately until proven by the patient. non-infectious (non-covid19)[18]. In accordance with the Guidelines for covid19 Patient Services in the emergency room by HIPGABI in 2020 which states that the primary triage study focuses on the initial complaints of the patient coming to the emergency and a history of contact with covid19 patients or a history of going to places where covid19 is indicated before the patient enters the hospital service unit. However, on observations of the study, it was found that emergency room patients were not subjected to primary triage for screening[19].

The triage was only carried out while in the emergency unit. This happened because the special emergency room was not separate from the general emergency room. This was confirmed by the results of an in-depth interview with the head of the emergency. Based on the results of an in-depth interview with the head of the emergency said that this happened due to the absence of a primary triage room to screen patients and their families who were admitted to the emergency, the absence of the RSKJ Soeprapto Bengkulu Emergency Service Guidelines in the era of covid19 which was clear, there was no special team of experts[20]. to screen patients and 
families of emergency room patients, and the absence of routine socialization of service standards in the era of covid19[21].

In principle, its implementation in the absence of primary triage before entering the emergency room and screening for covid19 in the emergency room resulted in the long duration of emergency services at RSKJ Soeprapto Bengkulu, which led to stagnation of patients which eventually led to overcrowding in the emergency room. In addition to the causes explained by the head of the emergency room above, the cause of the error in RSKJ Soeprapto Bengkulu's emergency service standards in the covid19 era also occurred because of waste. In this study, the researcher developed waste into a theory of the relationship between waste owned by Lean Management which only connects seven wastes, which is called the seven wasterelationship[17]. The researchers added that the waste owned by Lean Hospital consisted of eight wastes, of which the eight were waste of skills or talent or potential. This is because researchers consider that the waste of skill or talent or potential also has a strong relationship between other wastes[6]. If a health service such as in this study is a hospital that cannot form job satisfaction for its employees, or misplaces employees in units that do not match their potential, another waste will appear in every flow of the hospital service process[22]. This study proved the theory emerged in the form of the Lean Hospital and Modification Waste Assessment Model (MWAM) while adhering to the basic theoretical principles issued in this study. So that the number of questions that should arise is 186 to 264 (44 relationships x 6 questions).

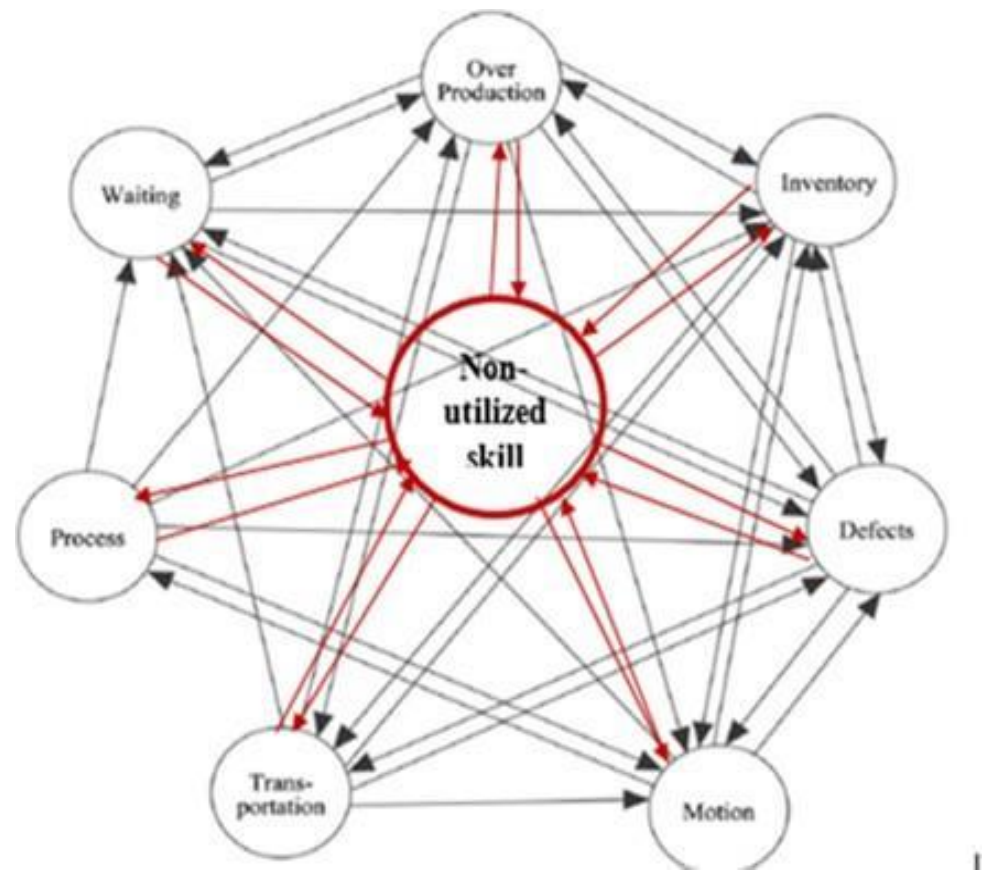

Fig. 4. Eight Waste Relationship of Lean Hospital Modification and WAM 


\begin{tabular}{|c|c|c|c|c|c|c|c|c|}
\hline From/To & O & I & D & M & T & P & W & S \\
\hline O & A & I & I & I & E & X & E & I \\
\hline I & I & A & I & I & I & X & X & I \\
\hline D & I & I & A & I & E & X & E & E \\
\hline M & X & I & E & A & X & X & E & E \\
\hline T & I & I & I & I & A & X & E & I \\
\hline P & I & O & I & E & X & A & E & E \\
\hline W & I & O & E & X & X & X & A & I \\
\hline S & I & I & E & E & I & E & E & A \\
\hline
\end{tabular}

Fig. 5. Results of Waste Matrix Value for Hospital

The results of the analysis based on lean modification and WAM with eight waste relationships (Figure5 and Figure6) found that the waste of human skills is critical waste which causes errors in emergency patient service standards in the era of covid19 with a value of $17.5 \%$. Followed by waste of over production by $14.3 \%$, and waste of over processing by $13.7 \%$.

\begin{tabular}{|c|c|c|c|c|c|c|c|c|c|c|}
\hline From/To & $\mathbf{O}$ & $\mathbf{I}$ & $\mathbf{D}$ & $\mathbf{M}$ & $\mathbf{T}$ & $\mathbf{P}$ & $\mathbf{W}$ & $\mathbf{S}$ & $\sum$ & $\%$ \\
\hline $\mathbf{O}$ & 10 & 6 & 6 & 6 & 8 & 0 & 8 & 6 & 56 & $14,3 \%$ \\
\hline $\mathbf{I}$ & 6 & 10 & 6 & 6 & 6 & 0 & 0 & 6 & 40 & $10,6 \%$ \\
\hline $\mathbf{D}$ & 6 & 6 & 10 & 6 & 8 & 0 & 8 & 8 & 52 & $13,4 \%$ \\
\hline $\mathbf{M}$ & 0 & 6 & 8 & 10 & 0 & 0 & 8 & 8 & 40 & $9,1 \%$ \\
\hline $\mathbf{T}$ & 6 & 6 & 6 & 6 & 10 & 0 & 8 & 6 & 48 & $12,6 \%$ \\
\hline $\mathbf{P}$ & 6 & 8 & 6 & 8 & 0 & 10 & 8 & 8 & 54 & $13,7 \%$ \\
\hline $\mathbf{W}$ & 6 & 8 & 8 & 0 & 0 & 0 & 10 & 6 & 38 & $8,8 \%$ \\
\hline $\mathbf{S}$ & 6 & 6 & 8 & 8 & 6 & 8 & 8 & 10 & 60 & $17,5 \%$ \\
\hline Total & 46 & 56 & 58 & 50 & 38 & 18 & 58 & 58 & 388 & $100 \%$ \\
\hline
\end{tabular}

Fig. 6. Results of the Waste Matrix Value Conversion in Hospital Waste of human skills or talent or potential, which is related to the motivation and psychological condition of employees in carrying out work, not taking advantage of employee creativity, improper placement of employees, not supporting staff to develop their careers, and ignoring staff skills and talents [17]. Based on the modification of the waste relationship matrix, the waste of human skills or potential or talent is closely 
related to generate the other seven wastes in service. The waste of human skills must be eliminated and recommendations for continuous improvement are found to improve emergency services in the era of covid19 [23].

\section{CONCLUSION}

The problems that arise from the critical waste of human skills, the researcher analyzes the causes of the problem using the fishbone method, so it is known the root cause of the problem of the emergence of waste of human skills in the service flow of inpatients from the emergency room during the covid19 pandemic. Researchers found that many emergency room and hospital staff did not understand the flow of patient services in the covid19 era and also did not fully understand what covid19 was. The discovery of waste of human skills in this study is in accordance with reality as well as the conditions during the observation made by the researcher. In addition, in the observation, researchers also found that there was a mismatch in the placement of covid19 screening officers and the number of officers complaining about the service flow policy that had been set. Conclusion according to Figure 2 to Figure 4 above:

a. The number of human resources in emergency services in the covid19 era is still insufficient;

b. Unclear patient care policies in the covid19 era especially for the mental health with difficulty and quickly assest

c. Work safety culture towards employees and patients is still lacking about all the emergency covid19 patient.

d. The flow of patient care in the covid19 era is not well socialized and not communication to patients, family of the patients also staff; and

e. The emergency service policy for emergency patients in the era of covid19 is not in accordance with the protocol set by the Ministry of Health and WHO

The research findings the causes of the problems that emerged, the recommendations for continuous improvement for RSKJ Soeprapto Hospital Bengkulu emergency services during the covid19 pandemic based on in-depth interviews with more than 15 (fifteen) persons also experts involved to making of guidelines for hospital emergency services during the covid19 pandemic, service guidelines during the covid19 period, carrying out covid19 screening for patients. The emergency room before the patient enters, and fill in forms a covid19 team and creates education and training programs about covid19 and managerial hospital issues regarding covid19. In order to improve hospital services in the future, it is necessary to form a covid19 team, to develop standard emergency service guides. Among the pandemic era it is important to conduct continuous socialization to all the hospital staff through education and training programs, which are recommendations for improving emergency services at RSKJ Soeprapto Hospital Bengkulu also for the new normal preparation. 
In the future the hospital management can be continues to carry out infection prevention and control strategies according to the expected standards and current procedures. Based on the results of this study, next research can be concluded that the waste of human skills in each service process is closely related to other wastes so that it needs to be the main focus for elimination, especially in the era of covid19. Eliminating or recalculating waste of human skills in emergency services during the covid19 pandemic will maintain the quality of service by preventing the accumulation of patients, due to the long service process and changes in service flow.

\section{ACKNOWLEDGMENTS}

The authors are grateful to the hospital BOD and the management of RSKJ Soeprapto Hospital Bengkulu Province, Indonesia for supporting this research, also special thank to Professor Lia Amalia for the invaluable support and advices.

\section{REFERENCES}

[1] WHO, "Together on the road to universal health coverage: A call to action," World Heal. Organ., 2017.

[2] A. D. Intiasari, J. Hendrartini, and L. Trisnantoro, "Analisis pola pemanfaatan jaminan pembiayaan kesehatan era Jaminan Kesehatan Nasional pada peserta non PBI mandiri di wilayah perdesaan Kabupaten Banyumas," Jkki, 2016.

[3] Joint Commission International, "JCI Accreditation Standards for Hospitals," Jt. Comm. Int. Accredit. Stand. Hosp., 2015.

[4] BPJS, "BPJS Kesehatan," Badan Penyelenggara Jaminan Sosial, 2017. .

[5] F. Tania and H. Thabrany, "Biaya dan Outcome Hemodialisis di Rumah Sakit Kelas B dan C," J. Ekon. Kesehat. Indones., 2017, doi: 10.7454/eki.v1i1.1763.

[6] H. T. Indra Rachmad Darmawan, "Refleksi Implementasi Jaminan Kesehatan Nasional pada Pelayanan Kedokteran Gigi di Fasilitas Kesehatan Tingkat Pertama Kota Tangerang Tahun 2017," Jurnal Kebijakan Kesehatan Indonesia : JKKI. 2017.

[7] J. J. Cavallo and H. P. Forman, "The economic impact of the COVID-19 pandemic on radiology practices," Radiology, 2020, doi: 10.1148/radiol.2020201495.

[8] S. Folland, A. C. Goodman, M. Stano, S. Folland, A. C. Goodman, and M. Stano, "Economic Efficiency and Cost-Benefit Analysis," in The Economics of Health and Health Care, 2018.

[9] R. Khana, M. M. Singh, F. Damanhoori, and N. Mustaffa, "Investigating the importance of implementing ethical value on a healthcare system within a social media context," Int. J. Innov. Creat. Chang., vol. 12, no. 5, 2020.

[10] R. Agustina et al., "Universal health coverage in Indonesia: concept, progress, and challenges," The Lancet. 2019, doi: 10.1016/S0140-6736(18)31647-7.

[11] L. Trisnantoro, "Universal health coverage and medical industry in 3 Southeast Asian countries," BMC Public Health, 2014, doi: 10.1186/1471-2458-14-s1-i3.

[12] H. Li and P. Hilsenrath, "Organization and finance of China's health sector: Historical antecedents for macroeconomic structural adjustment," Inq. (United States), 2016, doi: $10.1177 / 0046958015620175$.

[13] E. P. Mahadewi, A. Heryana, and S. Kuswanti, "Kepuasan Layanan Pasien Jkn Berhubungan Dengan Kinerja Petugas Kesehatan,” J. Bunga Rampai, 2019.

[14] Marhaeni, Z. Fanani, B. Hartono, and B. A. Nugroho, "The influence of the marketing mix (Product, price, promotion, place, process, entrepreneurs and physical evidence) to customer satisfaction and loyalty in buying shredded beef in Palu City, Indonesia," Int. 


\section{J. Econ. Res., 2015.}

[15] C. F. Hofacker, E. C. Malthouse, and F. Sultan, "Big Data and consumer behavior: imminent opportunities," J. Consum. Mark., 2016, doi: 10.1108/JCM-04-2015-1399.

[16] C. E. Phelps, Health economics. 2016.

[17] A. Ambarriani, "Hospital Financial Performance In the Indonesian National Health Insurance Era," McKinsey Q., 2014.

[18] F. Di Gennaro et al., "Coronavirus diseases (COVID-19) current status and future perspectives: A narrative review," International Journal of Environmental Research and Public Health. 2020, doi: 10.3390/ijerph17082690.

[19] E. P. Mahadewi, A. Heryana, Y. Kurniawati, and I. Ayuba, "Analisis Waktu Tunggu Pelayanan Poliklinik Paru di Rumah Sakit Umum Daerah (RSUD) Tangerang," Gorontalo J. Public Heal., 2019, doi: 10.32662/gjph.v2i1.463.

[20] World Health Organization, "Noncommunicable Diseases Country Profiles 2018," World Health Organization, 2018. .

[21] H. Thabrany and Z. Abidin, "Evaltuation of The National Drug Formularium and Electronic Catalog For The Indonesian UHC," Value Heal., 2017, doi: 10.1016/j.jval.2017.08.2749.

[22] F. Ihler and M. Canis, "The role of the internet for healthcare information on ENT specific issues," Laryngorhinootologie., vol. 98, 2019, doi: 10.1055/a-0801-2585.

[23] W. Quentin et al., "Paying hospital specialists: Experiences and lessons from eight high-income countries," Health Policy (New. York)., 2018, doi: 10.1016/j.healthpol.2018.03.005. 